\title{
Deep Impact and the Tail of Colonialism
}

This paper will critically reflect on the impact of colonialism on Te Reo Māori (the Māori language) through the analytical lens of political theory. The title of this paper is, "Deep Impact, and the tail of Colonialism", as this paper progresses it will become clear as to why this particular title was chosen.

Most languages around the world have, and continue to utilise the sometimes abstract nature of proverbs, metaphor, analogies, parables or the many other forms of figurative language, to explain, describe, evaluate, entertain or express themselves (Sharifian, 2011). For many indigenous cultures the use of this figurative language is an integral part of their language makeup (Sharifian, 2011). Te reo Māori is no exception. Proverbs, metaphor and other types of figurative language are woven deep within the fabric of te reo Māori and the Māori culture (Grove \& Mead, 2001, Mead, 2003).

Whether using formal or informal speech, Māori people use figurative language to express and explain a multiplicity of emotions, such as, elation, dread, happiness, anger, trust and suspicion (Mead, 2003). It is noticeable that this figurative language is more ubiquitous or prevalent when Māori are writing or discussing their language and culture (Grove \& Mead, 2001, Mead, 2003). From a Māori world view, the deep seated feelings associated with language and cultural decline are only sufficiently articulated through the use of metaphor, proverbs or other forms of figurative language, as the following 
paragraphs attempt to demonstrate (Grove \& Mead, 2001, Mead, 2003).

Colonialism struck the indigenous world with the destructive force of a massive comet, and its impact will be forever etched in the cultural memories of its entire people. The force of the comet has left a crater (within the indigenous world) so deep and terrible that those indigenous peoples, who survived the transformational collision, are still fighting to ascend from the crater floor. Despite the best efforts of Indigenous peoples worldwide, to rise above this cataclysmic event, their efforts continue to be hampered by the tail of the comet or what can be referred to as "lasting colonialism". This lasting colonialism continues to distribute its toxic elements within the ever fragile environment of the indigenous world.

While the impacts of this catastrophic event have been written about and analysed across the indigenous and non indigenous world for many years, the far reaching implications of this transformational collision are only now being fully realised through the ongoing studies of indigenous and non indigenous researchers. Indigenous peoples and people of conscience are continuing to identify and define, through critical analysis, the historical impacts of colonialism and how these impacts underpin the ongoing forms of racism, discrimination, negative stereotyping and ultimately contribute to the decline of indigenous languages and cultures worldwide.

This ongoing situation was the catalyst for my decision to undertake research that could be used to deconstruct the aging edifice of colonialism and identify the ongoing impacts that contribute to the decline of te reo Māori and other indigenous languages. I started my thesis by researching the whakapapa (the genealogy) of te reo Māori. I then researched the negative effects colonialism has had and continues to have on te reo Māori and the Māori culture. Once I had completed this research, I began to critically analyse the information using the theories and ideas of political theorists such as Plato, Niccolo Machiavelli, Georg Hegel, Karl Marx and 
Freidrich Engels, Antonio Gramsci, Paulo Freire, Frantz Fanon, Michel Foucault, Edward Said, Ngugi Wa Thiong, Henry Giroux and Haunani-Kay Trask, all theorists, all writers with their own unique interpretation and view of political tactics and strategies.

For this paper I have elaborated on a number of the theorists that I researched in my thesis. In the first instance I have given brief examples of some of their theories and ideas. I have then applied these theories and ideas within a Māori context. The following are the theorists that I choose.

\section{Frantz Fanon}

Frantz Fanon has written extensively about colonisation and the coloniser. His book 'The Wretched of the Earth' describes the mind-set and deep rooted fears of the colonist (Fanon, 1963). In Wretched of the Earth Fanon writes,

The colonial world is a Manichaean world. The colonist is not content with physically limiting the space of the colonized, i.e., with the help of his agents of law and order. As if to illustrate the totalitarian nature of colonial exploitation, the colonist turns the colonized into a kind of quintessence of evil. Colonized society is not merely portrayed as a society without values. The colonist is not content with stating that the colonized world has lost its values or worse never possessed any. The "native" is declared impervious to ethics, representing not only the absence of values but also the negation of values. He is dare we say it the enemy of values. In other words, absolute evil. A corrosive element, destroying everything within his reach, a corrupting element, distorting everything which involves aesthetics or morals, and agent of malevolent powers, an unconscious and incurable instrument of blind forces (p.6).

Fanon's 'The Wretched of the Earth', is a brilliant analysis of the psychology of the colonised and their path to liberation, bearing singular insight into the fury and frustration of colonised peoples and the role of violence in achieving 
historical change (Fanon, 1963). This book astutely assaults the twin perils of post-independence colonial politics, the disenfranchisement of the masses by the ruling class on the one hand and intertribal and interfaith animosities on the other (Fanon, 1963). Fanon's analysis, a veritable handbook of social restructuring for leaders of emerging nations, has been mirrored all too clearly in the corruption and violence that has and continues to plague present-day Africa.

Fanon delves into the entire tribulation of colonisation from the spasms of colonised animosity, armed conflict and the destruction of the colonial bourgeoisie (Fanon, 1963). He analyses the role of class, race, national culture and violence in the struggle for national liberation (Fanon, 1963). Fanon examines the psychological effects of colonialism on indigenous populations and explores in-depth the psychological effects of colonial warfare (Fanon, 1963). Fanon asserts that even after nationalism is achieved, the indigenous population will continue to be affected by the psychological effects of colonisation (Fanon, 1963).

Fanon probes the economic section of decolonisation which demonstrates his support for a redistribution of wealth and a unification of resources (Gordon, Sharpley-Whiting \& White, 1996). Fanon explains that in his view colonisation is a military project, thus he promotes force by the colonised against the coloniser to achieve freedom (Fanon, 1963). Fanon examines Western attitudes towards the colonised, including awareness of colonial conditions and the kinds of people that emerge from both worlds (Fanon, 1963). The conclusion to Wretched of the Earth demonstrates Fanon's promotion for change when he calls for the Third World to create a distinct delineation between itself and Europe in order to create, a new man (Fanon, 1963). He details the psychological impact colonisation has had on the colonised and the coloniser (Fanon, 1963). Fanon concludes that colonisation has led to self-hatred among the colonised and pathological delusions of grandeur among the colonisers, thus his suggestion for the 
Third World to create a new man through engaging in bloody anti-colonial revolution (Fanon, 1963).

With reference to Aotearoa/New Zealand, Fanon's assertions can be applied to Māori and Crown relations reflected in the numerous attempts by the Crown, through Western conventions including Christianity, education, and law, to extinguish the Māori language and culture. For example, the 1847 Education Amendment Act was a guise for assimilation as it authorised the expenditure of public funds to set up and maintain schools that would teach only in English and included religious instruction and industrial training in their curriculum (Campbell \& Sherington, 2007). Another example is the 1907 Tohunga Suppression Act which outlawed various Māori experts from practicing and imparting their knowledge, in particular, traditional Māori healers and producers of Māori rongoa (Māori forms of medicine) (Campbell $\&$ Sherington, 2007). Fanon asserts that the native is seen by the coloniser as unredeemable, this attitude is reflected in Aotearoa by the high incarceration numbers of Māori, and the Government's persistent attitude of harsher penalties including government vacillation in considering Māori views to the alternatives of incarceration.

Fanon's notions of redistribution of wealth and unification of resources can be seen in the aspirations of iwi (tribes) through submissions to the Waitangi Tribunal concerning Māori grievances for past injustices. The return of ancestral lands to iwi, through the recommendations of the Waitangi Tribunal, can be seen as unification of resources, although in this circumstance, the land can be referred to as a traditional resource. Fanon (1963) argues that only through anti-colonial revolution can the Third World move beyond colonialism and start anew. By comparison, Māori must create a revolution of change through the denunciation of ruling class ideology within the government and mainstream institutions that negate the Māori language and a Māori world view. 
Through the critical lens of political theory, Māori and non-Māori who are involved in the struggle for Māori language survival can begin to recognise and deconstruct the ongoing perils of colonialism. This could lead to a revolution of Māori language revitalisation in terms of neutralising the negative effects of lasting colonialism. By understanding what affects the Māori language and a Māori world view, appropriate groups can be approached for their assistance, groups such as the Māori Political Party, the Mana Political Party or other Māori and non-Māori politicians and organisations who can lobby for change.

\section{Edward Said}

In his book 'Culture and Imperialism' Edward Said examines what he describes as imperialism in European literature (Said, 1993). He illustrates the broad grasp of imperialism and the tenure of one culture or group of people by another through analysis of Western authors and texts (Said, 1993). Said defines imperialism as an ideology; a set of assumptions that justifies, supports, and legitimates the conquest, control, and domination of lands that are inhabited by other people (Said, 1993). According to Said, imperialism as an ideology is distinct from colonialism which is the actual activity of dominating other lands and people through fear of physical and economic force (Said, 1993). Furthermore, imperialism goes beyond the political and economic domination and stays in a culture in the most subtle of ways (Said, 1993). One of the main themes in 'Culture and Imperialism' is the interconnection between culture and society whether in the past or the present.

In his book 'Culture and Imperialism', Said does not purposely intend to denigrate the West, but attempts to show how one's identity is determined by one's relationship with what he refers to as the 'Other' or the Third World (Said, 1993). Said discusses Western cultural representations of the non-European world, representations which have a tendency 
to be crude, racist and suffer from a chronic case of reductionism (Said, 1993). He believes this tendency is not accidental but a systematic element of an imperial inclination that suffers from the need to dominate (Said, 1993). Said, writes that the voices of the non-European world in Western culture are not likely to be heard to any significant degree, and are deliberately suppressed by imperialism (Said, 1993). According to Said (1993) politics and culture are one and the same. The developed world depends on the developing world, even though in cultural interpretations, the former often represents itself as separated and elevated from the latter (Said, 1993).

Said examines the power of literature to form and maintain ideological control over cultures, their history, people and how Western literature, the words and ideas, have affected and continue to affect non-Western cultures (Said, 1993). Said's observations go a long way in supporting his assumption that imperialism did not end after decolonisation and that there is still an intense need to justify domination in cultural terms (Said, 1993). Imperialism is viewed by Said as existing both in the material world and in the imagination. This view gives reason for his focus on Western literature (Said, 1993). Thus decolonisation does not put an end to the influence of imperialism in the practices of a nation (Said, 1993). Said's 'Culture and Imperialism' reveals that the tools used by Western imperialism to dominate other cultures are literary in nature as much as they are political and economic (Said, 1993). Said explores Western fiction and contemporary mass media and see them as weapons of conquest, he also analyses the rise of oppositional indigenous voices in the literatures of the 'colonies' (Said, 1993). He argues that dominant cultures of imperialistic powers are connected through strong ideological ties to their nations (Said, 1993).

For Māori, Western literature has permeated every aspect of Māori thought. From the arrival of the missionaries, and their religious doctrine, through to the establishment of 
colonial rule in Aotearoa, the Māori language and culture have been impacted upon. The attitudes of the ruling class towards the Māori language and culture in the $19^{\text {th }}$ century were openly antagonistic and hostile. These negative attitudes towards the Māori language and culture continue to prevail in many institutions across Aotearoa, but the hostility has become more subtle in its delivery (Walker, 2001).

The mass media in all its forms plays a more prominent role in reinforcing ruling class ideology than it ever has. Māori are continually depicted in a negative light through the newspapers, books, magazines and other forms of literature and media. Negative attitudes concerning the Māori culture and its language have been present in literature for many years. Through Said's theory, indigenous cultures, including Māori, are encouraged to analyse the impact of colonialism on their languages and cultures as a result of Western literature and not just of the economic and political reasons frequently espoused. If indigenous perspectives are distorted, or for the most part, made inconsequential by these types of literature, the non-indigenous world will forever suppose an altered perspective of indigenous peoples, their languages and cultures. With the exclusion of a Māori context, or a true reflection of an indigenous Māori world view from literature of this nature, the chance for the survival of te reo Māori and the Māori culture, in its proper condition, is markedly diminished.

\section{Antonio Gramsci}

Heralded as one of the major political and social theorists of the 20th century Antonio Gramsci's ideas and theories have had an influence in many fields of study, in particular educational theory and practice (Fontana, 2002). Furthermore, through his ideas and theories concerning the development of Western Marxism, he is considered to be one of the most important Marxist thinkers of his time (Fontana, 2002). Gramsci wrote 30 notebooks and around 3000 pages of history 
and analysis after being imprisoned by Mussolini's fascist dictatorship in 1926. These writings are known as the 'Prison Notebooks' (Booker, 2005; Fontana, 2002; Germino, 1990; Woodfin, 2004). The political and social theories of Gramsci lay at the axis of the concept he refers to as 'hegemony' (Booker, 2005; Fontana, 2002; Woodfin, 2004).

A concept that endeavours to explicate the reasons why workers might not be revolutionary and why they may even turn fascist (Booker, 2005; Fontana, 2002; Woodfin, 2004). Gramsci concluded that Karl Marx's original theory of economic determinism, referred to by Marx as the iron rules of economics, is flawed (Fontana, 2002; Woodfin, 2004). Gramsci disagreed with Marx's notion that only the industrial proletariat are able to carry out the revolution (Fontana, 2002; Woodfin, 2004).

Marx was adamant that historical change must be clarified in terms of the economic substructure (Woodfin, 2004). Furthermore, he stated that the superstructure of institutions like religion, law, and culture is always inferior to the economy, and changes of social values in the superstructure are determined by economics (Woodfin, 2004). Gramsci replaced Marx's theory of economic determinism with explanations of social change that lay in the superstructure and were determined by ideas rather than the economy (Woodfin, 2004). Gramsci argues that there are two ways the capitalist bourgeoisie class are able to dominate the proletariat, first economically and physically, through fear of losing one's job and by utter force, or alternatively by controlling the ideas, the very ideology of the workers (Pilario, 2005; Woodfin, 2004). Gramsci states that economic or physical force alone is not enough to ensure control by the bourgeoisie of the proletariat, so a system that could control the ideology of society, a system that could manipulate social consciousness had to be introduced (Woodfin 2004). Gramsci referred to this control of ideas as hegemony and characterised it in this manner; agreement from the majority of a society for 
the "picture of life" that is represented by those in power. The values, both moral and political, involved in this agreement will be largely those of the ruling class. The ideology comes to be seen as evident "commonsense" by the majority of people. It becomes "natural" to think like that. The consent is arrived at largely peacefully, but physical force can be used to support it against a dissident minority, so long as the majority acquiesce (Woodfin, 2004, pp. 25).

Gramsci cites that ruling class ideology is transformed into an acceptable culture (a world view) for the majority of society through the function of hegemony (Pilario, 2005; Woodfin, 2004). This culture eventually becomes accepted as a normal part of society and is promoted by the ruling class and adhered to by the subordinate class (Pilario, 2005; Woodfin, 2004). Culture in this sense is defined as a whole set of attitudes, values and norms that connect a particular society together into a working entity (Pilario, 2005; Woodfin, 2004). Historically it was mainly religious institutions or educational institutions that converted ideology into culture through the function of hegemony. Today mass media and its many institutions that produce the ideas, justifications, attitudes and perspective, form the fabric of everyday 'commonsense' (Pilario, 2005; Woodfin, 2004). Although, the bourgeoisie do not have exclusivity on hegemony, as Gramsci notes, in certain circumstances the proletariat is able to use it to their advantage, but they are unable to achieve this on their own and need the assistance of other exploited and disadvantaged groups (Pilario, 2005; Woodfin, 2004). In other words, revolution can take place but the alternative culture (world view) must be accepted by the widest range of exploited and disadvantaged groups (Pilario, 2005; Woodfin, 2004). Jones (2006) states;

Antonio Gramsci (1891 - 1937) recognized that social power is not a simple matter of domination on the one hand and subordination or resistance on the other. Rather than imposing their will, 'dominant' groups (or, 
more precisely, dominant alliances, coalitions or blocs) within democratic societies generally govern with a good degree of consent from the people they rule, and the maintenance of the consent is dependent upon an incessant repositioning of the relationship between rulers and ruled. In order to maintain its authority, a ruling power must be sufficiently flexible to respond to new circumstances and to the changing wishes of those it rules. It must be able to reach into the minds and lives of its subordinates, exercising its power as what appears to be a free expression of their own interest and desires. In the process, the ruling coalition will have to take on at least some of the values of those it attempts to lead, thereby reshaping its own ideals and imperatives (pp. 3 - 4).

Gramsci argues that the notion of achieving absolute power is a fallacy, but that maintaining power is a continuing process even during times when the ruling class is unable to maintain wider societal consent and the boundary between the demands of the dominant and the needs of the subjugated become the field of battle (Jones, 2006).

Gramsci's theory of hegemony when applied to a Māori context reveals some interesting perspectives. From the religious influences of the missionaries, followed by colonial influence and mass media in contemporary times, all in some way, have contributed to the distortion of Māori ideology, which inevitable has and continues to impact on te reo Māori and the Māori culture. Māori have been confronted with the two evils of ruling class exploitation, firstly economic and physical force, followed by the manipulation and control of Māori ideas and a Māori world view. This ideological control has in many instances transformed Māori ideology into 'popular culture' through the function of hegemony. A popular Māori culture that continues to be made more palatable by the ruling class to comfortable fit within its ideological borders. But this popular Māori culture has become unrecognisable by the culture it is supposed to represent and the impacts are being reflected in the decline of te reo Māori and its culture. It is difficult for many Māori to recognise these subtle changes. It 
is especially difficult for Māori youth to recognise and accept that this change is due to what Gramsci refers to as hegemony.

Māori youth and youth in general, consider popular culture to be their domain, their area of original ideas. This is the ideal place for the ruling class to practice hegemony, to begin to skew the ideas and world view of a whole generation of Māori youth who believe they themselves are the instruments of change through popular culture. Unfortunately, this is the same generation who are consistently told by the politicians, educationalists and mass media, which is controlled by the ruling class, that they will amount to nothing, that their future will ultimately include some form of abuse and incarceration. For youth, their belief that popular culture is their way of fighting the system or expressing their views is in actuality the very thing that exposes their vulnerability. These popular culture ideas are unable to include an authentic Māori context because they are filtered through a hegemonic world view which fundamentally opposes Māori ideology. A popular Māori world view merely implies an authentic Māori perspective, but in reality this view is fashioned and promoted by the ruling class and endorsed by the subjugated as common sense through hegemony.

\section{Georg Hegel}

Born in 1770, Georg Wilhelm Friedrich Hegel, a German philosopher, is known as one of the founding figures of German Idealism (Pinkard, 2001). Hegel was heavily influenced by Plato's theory that only thoughts are real, also Immanuel Kant's (a German philosopher), theory of transcendental idealism. Hegel formulated an elaborate system of historical development of ethics, government, and religion through the dialectical unfolding of the Absolute (Pinkard, 2001; Woodfin, 2004). Hegel is one of the most well-known historicist philosophers who lived through a number of major 
socio-political upheavals, such as, the American Revolution, the French Revolution, the Napoleonic wars and the aftermath of those wars in which Europe began its restructuring according to early nationalist principles (Pinkard, 2001).

Hegel followed all these events with great interest and in great detail, from his days as a seminary student in the late 1780s through his various appointments in high school philosophy departments and on to his days as the foremost intellectual of his time (Pinkard, 2001). The 'Philosophy of History', like his first major work, the 'Phenomenology of Spirit' strives to show how these major historical upheavals, with their apparent chaos and widespread human suffering, fit together in a rational progression toward true human freedom (Pinkard, 2001). Hegel provides answers into the process of how ideas unfold through his theory of the dialectic. Woodfin (2004) writes Hegel apportioned three laws to this theory, these are as follows: The Law of the Transformation of Quantity into Quality. According to Hegel, things tend to change gradually - quantitatively - for the most part, but will sometimes make a sudden leap in a different state. This is a qualitative change that can only happen after a period of quantitative change. The second law is The law of the Unity of Opposites. Many and perhaps all things in the world exist in opposition, day and night, hot and cold, good and bad, near and far, but they do not really exist separately to each other. They form unions outside of which neither can exist. Day has no meaning without night, good without bad. The identity of each depends on the identity of the other. Finally, Hegel's law of The negation of the negation. Any thesis contains within itself problems and difficulties (contradictions) which will bring about its downfall. This downfall is actually achieved by the antithesis which reveals the contradictions. Thus it negates the thesis. But the antithesis itself contains its own contradictions which are exposed by the synthesis. Thus the negation is itself negated (pp. 24-26). 
Hegel argues that every theory (thesis) or idea, apart from the absolute, has a weakness (antithesis), some aspect which would either be incomplete or false leaving the idea or theory open to contradiction, or what Hegel refers to as negation (Woodfin, 2004). The opposition of these ideas would only be eliminated when a third explanation is introduced; this Hegel refers to as the synthesis (Woodfin, 2004). The first aspect or original idea is the thesis, the idea that contradicts the thesis is the antithesis and the idea that leads to reconciliation is the synthesis (Woodfin, 2004). Hegel argues that over time the synthesis itself will inevitably be found to have deficiencies whereby the whole process will begin again until the absolute is established (Woodfin, 2004).

Hegel's best-known and most difficult concept is 'Spirit'. The basic notion is that all of human history is guided by a rational process of self-recognition. A process where human participants are guided to an ever increasing level of selfawareness and freedom by a rational force that transcends them, Hegel emphasises that we need not think of Spirit as God (Bhaskar, 2008). The only interest of this Spirit or force is to realise its own principle of true freedom (Bhaskar, 2008). It does this by unfolding as human history, where the consciousness of freedom is the driving force (Bhaskar, 2008). A primary feature of the operation of Spirit in history is that its nature is self-reflective (Bhaskar, 2008). Human history progresses as humans become increasingly self-aware and correspondingly become aware of their freedom (Bhaskar, 2008). Hegel captured something fundamental in history when he traced the development of freedom, but he perhaps overlooked the connection of freedom to the biological core of human beings. At this core, humans are immersed in selfinterest, in spite of those who purport humans have a great capacity to operate for the good of the whole. In this view of the world, self-interest confronts self-interest. Tension and conflict are resolved through cooperation until new cycles of self-interest emerge that again must be dealt with, such as, 
changing power dynamics, new laws, etc... and this dialectical cycle endlessly repeats itself.

Perhaps perpetual conflict rather than the principle of freedom is the essence of human history. If we apply Hegel's dialectic within a Maori context then Aotearoa/New Zealand history could then look something like this. Māori language and culture develops within Aotearoa/New Zealand for about a thousand years, this development we will call the Māori cultural thesis. We then have the arrival of colonisers who bring with them their language, values and beliefs. Hegel's dialectic process thus begins in that Māori beliefs, values and practices are critiqued by the colonisers. For example, inappropriate dress (or lack thereof), glorification of fanciful deities, barbaric cultural practices, misguided cultural ideology, redundant culture and language, underutilisation of the land and its resources etc...etc... (Campbell \& Sherington, 2007; Hokowhitu, 2004; McCan, 2001; Walker, 1996; Walker, 2001). This we will call the colonisers antithesis. Negation of the Māori cultural thesis by the colonisers antithesis has been ongoing since the 17th century, so theoretically (according to the dialectical model of Hegel) what we see today as the Māori culture is actually a synthesis born of the colonisers antithesis relative to the Māori cultural thesis; a hybrid of both colonisers and Māori culture which could be argued creates a platform of commonality for both cultures to interact. However, Hegel's dialectical model in this instance is unable to be completed because the dominant culture is unwilling to have their culture their values and beliefs critiqued, which is how the synthesis is created. Within the colonisers mind, he sees his position as always being part of the antithesis. He critiques the practices and beliefs of the colonised cultures with the cruel intent of a vengeful stepfather, hell bent on the conformation of the unwanted additions to his world. His never ending self-righteous attitude and disapproving manner fortifies his position within the antithesis but should indigenous cultures speak from the position of the antithesis 
against his practices and beliefs they are labeled agitators, radicals or even terrorists, this is where the imbalance of Hegel's negation of the negation is created. The coloniser is threated when he is not in the position of the antithesis because his actions, practices and beliefs are held up for critique. Without a synthesis there is no outcome for the colonized cultures, therefore, the principle of true freedom can never be achieved. Within this predicament Hegel's dialectical model of spirit is initiated but it is wedged within the struggle of self-interest and lack of self-reflection, cooperation and collaboration.

\section{Karl Marx and Freidrich Engels}

Karl Marx and Freidrich Engels published the 'Communist Manifesto' in 1848, a piece of literature that is unsurpassed in its depiction of modern capitalism and the transforming power of industrialisation (Woodfin, 2004). Many have criticised this book for its utopian alternative to capitalism and espouse that capitalism did not fall as predicted by Marx \& Engels, which proves the unrealistic ideals of communism are unachievable (Woodfin, 2004). Marx \& Engels wrote that the industrial process destabilised all hierarchies and also destabilised all sacred and secular inherited beliefs and practices. It turned everything everywhere into an item for sale; its catchphrase was and still is 'profit' (Woodfin, 2004). The Communist Manifesto splits the world into two spheres, the Bourgeoisie, the owners of the means of production and the Proletariat, the workers (Engels \& Marx, 2008). The bourgeoisie all but destroyed feudal society, but at the same time, it created perhaps its greatest adversary, the proletariat (Engels \& Marx, 2008). Marx developed a theory of value where the value of goods and services are based firmly on the amount of labour that is put into them (Woodfin, 2004). Furthermore, Marx suggests that the surplus which goes to the capitalist as profit is in reality the property of the proletariat. Marx \& Engels 
introduced the notion of history as a class struggle (Woodfin, 2004). Within this notion, conditions and development of various strata of society are discussed, including freeman and slave, lord and servant, oppressor and oppressed (Woodfin, 2004). This notion demonstrates how the development of each social stratum in history gave rise to the inexorable historical process which would ultimately culminate in the rise of one working class (Woodfin, 2004).

Karl Marx was to have a profound influence on many of the great minds of his time and beyond. This includes Ludwig Feuerbach, Vladimir Lenin, Leon Trotsky, Antonio Gramsci, Fredric Nietzsche and many others that espouse the potential of Marxist ideology (Woodfin, 2004). Although Karl Marx has written many theories on many different issues, one particular theory of interest is his theory of 'alienation', a theory that is central to his concept of human nature (Churchich, 1990). According to Marx, humanity is realised through meaningful work that is interacting with nature and people in the process of making or changing things (Hodson \& Sullivan, 2008). However, through the alienating nature of capitalist types of work, humanity is robbed of its potential growth and development (Hodson \& Sullivan, 2008). In addition, Marx states that workers are treated by capitalists like an "inanimate factor of production" (Hodson \& Sullivan, 2008, p.8). That is to say capitalists own the means of production, the technology, capital investments and raw material and the basic aim of capitalists is to make profit by exploiting the poor and oppressed. This exploitation manifests itself through cheap labour and inhuman working conditions. To exacerbate this situation while the oppressed and poor become reliant on this degraded means of survival their working conditions are made worse by the capitalist in the pursuit of bigger profits. In the 'German Ideology' Marx (1970) states, "the ideas of the ruling class are in every epoch the ruling ideas, i.e. the class which is the ruling material force of society, is at the same time its ruling intellectual force" (p.64). In other words, if the 
individual ideas of the working class do not fit within the ideas of the ruling intellectual force, these ideas are never realised, therefore potential growth and development of the working class position is limited.

Marx's theory of alienation can be applied to the struggle of Māori to retain their own language, Māori as the working class and the Crown as the ruling class. Although Marx's idea of revolution by the proletariat to overthrow the Bourgeoisie (capitalists) did not eventuate, Māori protesting in all its forms concerning the continuing loss of the Māori language and culture can be likened to Marx's idea of revolution. Contemporary challenges for self-determination have taken many forms, as they did in earlier years. Through achievements in health, child welfare, employment and education Māori women have featured prominently, particularly through the Māori Women's Welfare League (Ka'ai, 2004; Linnekin \& Poyer, 1990). The literary medium has also been used for gain, predominantly newsletters, as well as the field of drama (Ka'ai, 2004). The 1970s saw Māori using the political arena by protesting and forming their own political parties, the emergence of language advocacy groups, the related Te Kōhanga Reo movement and the cultural renaissance concerning traditional Māori art forms was also a part of this era (Ka'ai, 2004).

Māori are not only continuing to protest but are joining the struggles of indigenous people worldwide to achieve selfdetermination (Ka'ai, 2004). Māori have fought on many levels for equality and indigenous rights expressed through “...lobbying, making submissions, presenting petitions, mounting deputations, to occupying land under dispute, establishing various movements, organising marches, protests, boycotts, pickets, symbolic acts, demonstrations and establishing political parties" (Ka'ai, 2004, p.181). As previously mentioned, Marx developed a theory of value for capitalistic ventures undertaken by the bourgeoisie. Within this theory, the value of goods and services are based firmly on 
the amount of labour that is put into them (Woodfin, 2004). Furthermore the surplus, which is the profit, goes to the bourgeoisie but actually belongs to the proletariat (Woodfin, 2004). If we quantify the amount of labour it would take to revitalise te reo Māori, using Marx's value theory, it can be seen that besides having no surplus for the capitalist, there is actually a large cost. In the eyes of the capitalist the profits are given to Māori, in terms of the survival of their language, therefore support is tempered with contempt and continual scrutinising of support. Māori on the other hand view the survival of te reo Māori as a profit for all of Aotearoa/New Zealand, where the surplus is measured in terms of cooperation, collaboration and respect borne through the processes of language revitalisation. Karl Marx and Freidrich Engels ideas and theories are at the very least considered by some as controversial and by others as threatening and dangerous to their world views. Be that as it may, there are many people from all walks of life who continue to research and write about Marx and Engels ideology and theories, whether in agreement or negation.

\section{Paulo Freire}

Paulo Freire was an educator/theorist who worked extensively in Latin America and former Portuguese colonies in Africa (Macedo, 2000). As an educator, he saw that he could initiate change by challenging and even defeating the exploitation and suffering that oppressive societies created by motivating the oppressed and finding new ways of approaching education (Macedo, 2000). For Freire, a person who could not read was no less intelligent than a person who could read, it is simply that he/she had not undergone the process of learning to read yet (Freire, 1970). Freire (1970) wrote the 'Pedagogy of the Oppressed' for those who believed that exploitation of the poor and oppressed in all societies should be eliminated. 
Furthermore he cites that, education is the greatest medium for change in all societies. Freire (1970) states;

This, then, is the great humanistic and historical task of the oppressed: to liberate themselves and their oppressors as well. The oppressors, who oppress, exploit, and rape by virtue of their power, cannot find in this power the strength to liberate either the oppressed or themselves. Only power that springs from the weakness of the oppressed will be sufficiently strong to free both (p.21).

Freire explains that liberation of the oppressed and oppressor can only be initiated by the oppressed, as they are not shackled by the addictive influence of power. This liberation must include change at the highest strata of politics, education and social culture to create a type of sustainable liberation (Freire, 1970). Freire (1970) argues that oppression dehumanises both the oppressed and the oppressors and proposes pedagogies based on trust for the oppressed and builds reflection that would ultimately lead to positive action by the oppressed. Freire (1970) dismisses the 'banking model' of education, where the student is seen as passive and knowledge is placed therein. Instead, he advocates problemsolving education, where the students become studentteachers and teachers become teacher-students. Freire (1970), outlines the conditions that must be met to empower the oppressed through education in his book, 'Pedagogy of the Oppressed'. His theories suggest that empowerment through education can only happen from the bottom up and that knowledge must be socially constructed for it to be meaningful.

'Pedagogy of the Oppressed' has its beginnings in Freire's life experiences, in particular his physical hunger as a child whose middle-class family fell from its economic podium and landed head first into the land of the poor (Macedo, 2000). Freire's experience of and confrontation with class borders would lead to his radical rejection of class-based society 
(Macedo, 2000). According to Macedo (2000) Freire understood that, "material oppression and the affective investments that tie oppressed groups to the logic of domination cannot be grasped in all of their complexity within a singular logic of class struggle" (p.13). Freire argues that a clear understanding of oppression inevitably takes a route through some form of class analysis, although it is impossible to "...reduce everything to class, [as] class remains an important factor in our understanding of multiple forms of oppression" (Macedo, 2000, p.14). The fundamental goal of Freire's pedagogical methods concerning education, is to heighten the student's level of consciousness of the world around him/her, while at the same time learning to read (Spring, 2006). Spring (2006) writes;

Reading has an important function in the operation of consciousness because, according to Freire, learning to read is a process of learning how to name the world. Language provides the tools by which people can think about the world and see the world as a place that they can change. As mentioned earlier in this chapter, Freire considers his pedagogical methods to be as easy to follow as a cookbook, but their implementation requires an understanding of his definition of human nature. The central feature of his method is dialogue. Freire's concept of dialogue is quite different from that of Socrates... (p. 151).

Dialogue according to Freire's method, is to help both the teacher and student understand the political, economic and social forces that have shaped their lives (Spring, 2006). Although teachers may possess a critical consciousness, they do not necessarily understand the fundamental aspects of their students' lives (Spring, 2006). The freeing of consciousness from a necrophilic personality (psychology longing for death) into a biophilic personality (love of life or living systems - attraction to all that is alive and vital) for all people, is a major goal within Freire's method of education (Spring, 2006). The freeing of consciousness is related to 
Freire's notion of revolutionary change and offers clear definitions of what he refers to as left and right revolutions (Spring, 2006). Freire considers the revolution in Russia as a revolution of the right considering there was simply a change of one set of authoritarian figures for another, implying the lack of revolution within the consciousness of the people (Spring, 2006). Spring (2006) illustrates the contrasts between Freire's notions of left and right revolutions within the following table.

Table of Left and Right Revolutions

\begin{tabular}{|ll|}
\hline \multicolumn{1}{|c|}{ Revolution of the Left } & \multicolumn{1}{c|}{ Revolution of the Right } \\
\hline - People are subjects of history & 1- Leadership knows the future \\
\hline $\begin{array}{l}\text { 2- Leadership and people work } \\
\text { together to develop utopian } \\
\text { vision }\end{array}$ & 2- People are domesticated \\
\hline 3 - Biophilic & 3- Necrophilic \\
\hline - - Love as liberation & 4- Love as possession \\
\hline 5 - Dialogue & 5 - Mutism \\
\hline 6 - Reflective-problematizing & 6- Slogans \\
\hline 7 - People who organize & 7 - Organization people \\
\hline 8 - Revolution continuous & 8- Bureaucracy \\
\hline
\end{tabular}

(Adapted from Spring, 2006)

The contrast between the two columns within this table reflects Freire's notion of the two forms of consciousness. Numbers 1 - 2 of the left revolution highlight the differences that are shared between people who are consciously working together to shape the future (Spring, 2006). Numbers 1 - 2 of the right revolution indicate self-proclaimed leaders deciding the fate of the people (Spring, 2006). Number 3 of the left revolution has already been discussed in the last paragraph and number 4 of the left revolution refers to Freire's idea of finding teachers who will initiate social change by developing their biophilic personality and combining it with revolutionary consciousness (also known as critical consciousness) (Spring, 2006). With these two aspects in mind teachers will be able to liberate their students through what Freire refers to as an 'act 
of love' (Spring, 2006). Number 3 of the right revolution has already been discussed in the last paragraph and number 4 of the right revolution indicates possession rather than liberation pertaining to the consciousness of the people/students (Spring, 2006).

Number 5 of the left revolution indicates people/students who are engaged in open dialogue while number 5 of the right revolution refers to keeping the people/students quiet by disallowing open dialogue (Spring, 2006). Number 6 of the left revolution promotes allowing people/students with problems to be solved through conscious reflection and dialogue, and 7 of the left revolution refers to the involvement of the people/students in organising for social change (Spring, 2006). Number 6 of the right revolution refers to revolutionary leaders hurling slogans at the people/students, treating them as objects rather than individuals while number 7 of the right revolution indicates people/students joining organisations developed by those in power (Spring, 2006). Number 8 of the left revolution indicates social change that remains continuous while people/students seek a better life and number 8 of the right revolution refers to bureaucracy that protects the newly won power of revolutionary leaders against any challenges (Spring, 2006).

Although Freire's discussion of curriculum deals mainly with the education of the poor and illiterate, Freire's life's mission was to help the poor and oppressed masses to gain insight into alternative ways of education (Freire, 1970). If we apply Freire's 'Left and Right Revolution' to the implementation of colonialism in all its forms, in particular its educational pedagogies within Aotearoa/New Zealand, we can gauge what side the revolution leans towards, left or right and perhaps gains some understanding as to why the Māori language and culture is in decline. The differences that exist between Māori and colonial pedagogies and ideologies are not acknowledged and open dialogue pertaining to the future of Aotearoa/New Zealand was non-existent. This implies a lean 
to the right for numbers 1 - 2 (Campbell \& Sherington, 2007). Negative colonial attitudes towards Māori tikanga and their insistent approach to what they refer to as the 'civilising of Māori' implies a desire, or longing, for the discontinuation, or death, of Māori practices and language (Binney, 2005). This implies a lean to the right for number 3. Persistent colonial attitudes that insist Māori must fall under the authority of British rule rather than being an independent ally to Britain suggests possession rather than liberation, implying a lean to the right for number 4 (McCan, 2001).

Māori have had little or no input into the running of Aotearoa/New Zealand following the signing of Te Tiriti o Waitangi (The Treaty of Waitangi), even though Te Tiriti o Waitangi was considered a partnership between Māori and the Crown (Walker, 1996). In fact New Zealand's third Chief Justice Judge Prendergast concluded that the Tiriti o Waitangi was a nullity and Judge Myers further reinforced that view (Walker, 1996). This implies a lack of dialogue and inclusion of Māori which leans toward number 5 right. The lack of dialogue and inclusion in 5 right applies to 6 right which suggests that people/students (Māori) are treated like objects rather than individuals. Māori were encouraged to participate in European forms of education established by the missionaries and then by the Crown and were actively discouraged from being involved in Māori pedagogy (whare wānanga) which implies a push towards institutions developed by the ruling class which is a lean towards 7 right (Campbell \& Sherington, 2007; Hokowhitu, 2004). The development of a New Zealand government that implemented rules and legislation that dramatically affected the status of Māori in Aotearoa/New Zealand indicates bureaucracy that protects the ruling class, which implies a lean to the right for number 8 (Walker, 1996). According to Freire's table of left and right revolution, the colonisation of Aotearoa, in all it forms, would be considered a complete right revolution and it could be said that its negative effects have led to the oppression of the Māori people, their 
language and culture. Accordingly, Māori society, before colonisation, could be described as a revolution of the left in most instances.

Without going into detail, I should state that all the political theorists, their theories, ideas and notions that I have researched can and have been used by me, within my thesis, to deconstruct, define and aid in the understanding of lasting colonialism and ultimately help in the struggle for the retention of te reo Māori and the Māori culture. I whānau mai au i roto I te nonoketanga, no reira ko au te nonoke, ko te nonoke ko au. I was born into the struggle, therefore, I am the struggle the struggle is me, nō reira tēna tātou katoa.

\section{BIBLIOGRAPHY}

Bhaskar, R. (2008). Dialectic: The Pulse of Freedom. New York, NY: Routledge.

Binney, J. (2005). The Legacy of Guilt: A life of Thomas Kendall. Wellington, New Zealand: Oxford University Press.

Booker, M. K. (2005). Encyclopaedia of Literature \& Politics. Censorship, Revolution, \& Writing (ed). Westport, CT: Greenwood Publishing Group.

Campbell, C., Sherington, G. (2007). Going to School in Oceania. Westport, CT: Greenwood Publishing Group Inc.

Churchich, N. (1990). Marxism and Alienation. Cranbury, NJ: Associated University Press.

Engels, F., \& Marx, K. (2008). Manifesto of the Communist Party and selected essays. Rockville, MD: Manor Thrift Publishers.

Fanon, F. (1963). The wretched of the earth. New York, NY: Grove Press.

Fontana, B. (2002). Hegemony and Rhetoric: Political Education in Gramsci. In C. Borg, J. Buttigieg \& P. Mayo (eds.), Gramsci and Education (pp. 25-40). Boston, MA: Rowman \& Littlefield Publishers.

Freire, P. (1970). Pedagogy of the oppressed. Baltimore, US: Penguin Books.

Gordon, R., L. Sharpley-Whiting, T., D. \& White, R. T. (1996). Fanon: critical reader.

Grove, N., \& Mead, H. M. (2001). Ngā Pēpeha a ngā Tīpuna. Wellington, New Zealand: Victoria University Press.

Hodson, R. \& Sullivan, T. A. (2008) The social organisation of work: Belmont CA: Thomson Higher Education. 
Hokowhitu, B. (2004). Physical Beings: Sport and the Physical Education of New Zealand Māori. In J. A. Mangan \& A. Ritchie (eds.), Ethnicity, Sport, Identity: Struggles for status (pp.191-218). Great Britain: Frank Cass Publishers.

Jones, S. (2006). Antonio Gramsci. New York, NY: Routledge Publishers.

Ka'ai, T. M. (2004) Te mana o te tangata whenua - Indigenous assertions of sovereignty. In Ka'ai, T., M. Moorfield, J., C. Reily M. P.J. \& Mosley, S. (eds.), Ki Te Whaiao: An introduction to Māori culture and society (pp.181-189). Auckland, New Zealand: Pearson Education.

Linnekin, J., \& Poyer, L. (1990). Cultural Identity and Ethnicity in the Pacific. Honolulu, HI: University of Hawai'i Press.

Macedo, D. (2000). Introduction. In P. Friere, Pedagogy of The Oppressed. (30th Anniversary ed., pp.11-27). New York, NY: Continuum.

Marx, K., Engels, F. (1970). The German Ideology. New York, NY: International Publishers Co.

McCan, D. (2001). Whatiwhatihoe, The Waikato Raupatu Claim. Wellington, New Zealand: Huia Publishers.

Mead, H. M. (2003). Tikanga Māori. Living by Māori values. Wellington, New Zealand: Huia Publishers.

Pilario, D. F. (2005). Back to the rough ground of Praxis. Leuven, Belgium: Leuven University Press.

Pinkard, T. (2001). Hegel: A biography. Cambridge, United Kingdom: Cambridge University Press.

Said, E, W. (1993). Culture and Imperialism. New York NY: Vintage Books. Massachusetts, MA: Blackwell Publishers.

Sharifian, F. (2011). Cultural Conceptualisations and Language: Theoretical Framework and Application. Philadelphia, North America: John Benjamins Publishing. Co.

Spring, J. H. (2006). Wheels in the head: Educational philosophies of authority, freedom, and Culture from Socrates to Human Rights. New Jersey, NJ: Lawrance Erlbaum Associates Publishers.

Walker, R (1996). Ngā Pepa A Ranginui: The Walker Papers. Auckland, New Zealand: Penguin Books.

Walker, R. (2001). He Tipua: The life and times of Sir Apirana Ngata. Auckland, New Zealand: Penguin Books.

Woodfin, R. (2004). Introducing Marxism. London, United Kingdom: Icon Books Ltd. 